\title{
The Relationship between the Disappearing Use Value of Urban Space and Gentrification: "Is Gentrification a Profitable Trade-off?"
}

\author{
Fatma Gozde Koseoglu ${ }^{1}$, Assoc. Prof. dr. Nihan Özdemir Sönmez ${ }^{2}$
}

\begin{abstract}
This paper investigates the lost use value of the city center within the framework of the property handover in Fikirtepe Regeneration Project and the gentrification process experienced by the old settlers. The paper aims to explain the nature of the change that takes place in the social structure of regeneration area and transforming of the city center's use value into the exchange value associated with the changing of social structure. The paper also aims to express what this replacement mean for old settlers and to discuss if the gentrification is a profitable trade-off for them. The data obtained from the questionnaires and the in-depth interviews conducted with the old settlers of regeneration area and the investors who prefer to buy real estate from the new projects in the region, have been analyzed in order to identify the relationship between the lost use value of the city center and the old settlers' perception regarding to the gentrification. The study demonstrates that: i) There is a sociocultural change in the regeneration area. ii) The old settlers of gentrified area and also the investors, perceive gentrification as a process of obtaining financial gain iii) The use value of the center disappears as a result of this perception of gentrification. Briefly, the paper aims to show a relationship between the lost importance of use value in urban space and gentrification process.
\end{abstract}

Keywords:: Urban Regeneration, Gentrification, Use Value, Exchange Value, Real Estate Economic Rents, Istanbul.

\section{Introduction}

Because of the differences in economic rent that emerges during the gentrification process, the gentrification projects realised in city centers result in change of property. During the process of change of property, that is, gentrification; the city center loses its use value for the old settlers of the urban regeneration area. However, during this process, the city center gains a new meaning that represents the exchange value, both for the old settlers and the new owners of the gentrified area. In other words, there is a causal link between the gentrification process and the lost use value of the city center. Therefore, the handover process in the gentrified area causes the city center to lose use value, transforming the value of the urban space to exchange value.

To put forth this relationship, this paper resorts to the questionnaires conducted with old settlers and new owners within the scope of the field study carried out in the Fikirtepe Urban Regeneration Area. The first questionnaire was conducted with the land holders and users living in the area being gentrified. Fikirtepe Urban Regeneration Area encloses the quarters of Dumlupınar, Eğitim, Merdivenköy, and Fikirtepe. According to

$\mid{ }^{1} \mathrm{PhD}$ Student in Ankara University, Turkey.

${ }^{2}$ Ankara University, Department of Real Estate Development and Management. 
the reports ${ }^{1}$ which laid the foundation for the regeneration plan prepared by The Ministry of Environment and Urbanisation in 2013; the number of people living in the project area is 50,000 , with an average household size of 3.25 people. According to TUIK, it is seen that there has been a decrease of 13,076 people in the total population of the mentioned four quarters since the start of the regeneration process. Bearing in mind that this decrease in the neighborhood population is due to the demolitions and evacuations in the urban regeneration area, it has been assumed that the current population is 36,924 , with an average household size of 3.25 people. On this basis, the target population for the survey to be applied to the land holders and users was determined to be 11,362 households. For calculating the proper sample to represent the target population consisting of 11,362 households, including land owners and users, the following formula was used: $\nu=\mathrm{N} \tau 2 \pi \theta / \delta 2(\mathrm{~N}-1)+\tau^{\prime \prime} \pi \theta$. Assuming the (d) value, which is the error margin rate, as 0.07 , and confidence interval as $95 \%$, field studies were launched with the aim of completing 193 questionnaires. As a result of the 2 -month field study, a total of 206 land owners and users were surveyed. In the other questionnaire, the investors who preferred to be landlords in the real estate projects realised in the area were surveyed. It is learned from the Kadıköy Municipality and the project developers that approximately 70,000 housing units are planned to be built in the risky area of the region. The same formula was used to determine the number of samples, and the confidence interval was assumed as 95\%. However, because of the adverse circumstances that made accessing the participants difficult, the (d) value, which is the error margin rate, was assumed as 0,10 . When these values are substituted in the formula; the number of elements in the sample set to be selected from the target population consisting of 70,000 residential investors was determined as 95.9. At the end of a twomonth-long survey study, 96 participants were surveyed as was intended.

\section{Briefly on Gentrification and the Rent-Gap Theory}

The increase in land value seen in urban regeneration processes leads to other changes in physical patterns as well as ownership patterns, in other words, urban regeneration projects turn into gentrification projects. Creating the urban land rents through ownership and land values, the urban regeneration process starts with the encounter of the lower class and the newly-emerging middle class, but it ends up with the lower class leaving the regeneration area (Sam 2010).

According to Harvey (2003), the capital takes action again and again in order to purge the capital rent areas off of immigrants and the poor. Furthermore, Harvey (2003) also points out that during the urban regeneration process, the public sector balances the destructive power of market change, and supports the structural conditions that the capital needs.

Neil Smith (1979), explains the regeneration process that he names as the revaluation of the capital, with the rent-gap theory. According to this approach, also known as the

\footnotetext{
${ }^{1}$ Kadiköy District Fikirtepe and Surrounding 1/5000 scale master development plan explanation report, accepted with Ministry approval dated 02.08.2013, numbered 12984, and 1/1000 scale implementary development plan explanation report
} 
critical approach, the bigger the rent-gap is the more attractive the city center becomes for the capital investments. The rent-gap in question reflects the difference between the "potential" and the "capitalised" values of a land (Soytemel and Şen 2014).

With better opportunities after the World War II, there were new policies employed to encourage the middle class and the working class to produce again. During this period, with the migration to the suburbs and the appreciation of the properties in the suburbs, the urban lands started to get empty. Therefore, in parallel with the capital movement towards new suburbs, city centers regressed and the land value gap between the two regions brought about the rent-gap (Smith 1996).

With the new search for profits acting on the global level by re-valuating the "underdeveloped" city areas to prevent the capital in the center from losing value, the "rent-gap" between the locations that lost value and the locations that gained value following industrialization (Smith 2002, Soytemel and Şen 2014) became an influential factor in the world geography (Şen 2011).

The Rent-Gap Theory correlates the capital investments that gravitate towards the areas in the city periphery and the capital gravitating towards the old city centers revaluated following this process, and it forms a relation of causality between the two (Sam 2010). The rent-gap in a region where the potential rent is high will put pressure to regenerate the buildings that fail to meet the needs that change with the new conditions and turn into unprofitable real estates (Smith 1996). During this process, the rent-gap attracts the capital investment to regeneration areas, because the rent-gap acts as an incentive for investing in the land (Smith 2002, Soytemel and Şen 2014).

Based on this explanation, it would be true to say that the biggest rent-gap will emerge in urban regeneration projects taking place in slum areas in central locations. The reason for the huge rent-gap is that the buildings in these slum areas have a high potential value at the end of the regeneration projects because of their central locations, despite the fact that they no longer meet the changing needs and they have turned into unprofitable real estates. Due to the huge rent-gap, the change in the broken-down physical pattern of the city center affects the ownership patterns, and the increase in value in the central urban areas results in gentrification. The central location of the regenerated urban area gains a new meaning reflecting the exchange value.

\section{Migration from the City Center}

The field study conducted in the Fikirtepe Urban Regeneration Area shows that the land owners moving from Fikirtepe are scattered across different areas of the Anatolian Side, and the study also underlines the fact that the majority of the land owners move away from the city center.

The questionnaires conducted within the field study show that almost all of the land owners remain in Istanbul, but they move away from the city center and gravitate towards the city peripheries.

A participant's words "Everybody has scattered along the rural area right above TEM. Not one person moved to Bagdat Caddesi." shows that the land owners remained in Istanbul but their movement was from the city center to the periphery.

The TEM Motorway, which starts from Europe and ends in Iran, has been one of the 
most crucial factors that determines the future of urban development in Istanbul, since the day it was opened to service. The settlements along the TEM that are close to the bridge connection points thrived in a short period of time, and the settlements with illegal housing that are enriched by the linking roads grew rapidly.(3. Bridge Evaluation Report) Therefore, by drawing a line between the priorly built-up central areas of the city and the rapidly growing and developing areas, it created an inner island. This imaginary line created by TEM Motorway sets a new central border that broadens the central borders that were determined by the first bosphorus bridge.

Chart 1. The distribution of the destinations of land owners who left Fikirtepe by the line that is assumed to determine the central borders

\begin{tabular}{|l|c|c|}
\hline Point of Departure & Number & Percentage (\%) \\
\hline Inner Island & 101 & 27.5 \\
Outside the Line & 266 & 72.5 \\
\hline Total & 367 & 100.0 \\
\hline
\end{tabular}

When the data obtained from the questionnaires conducted with the land holders and users from Fikirtepe is analysed, it is seen that $72.5 \%$ of the land holders from Fikirtepe headed towards the settlement areas outside the central line drawn by TEM. In other words, $72.5 \%$ of the land owners who sold their real estates and left Fikirtepe are pushed outside the line determined by the coastal road and TEM (Chart 1).

In short, the population who left the gentrified area moved from the city center to the periphery, and the majority of the land owners moved to different points outside the line that is assumed to represent the borders of the city center.

\section{Gentrification as a Profitable Trade}

The huge rent-gap emerging in the urban regeneration projects realised in city centers turns gentrification, which is inevitable most of the time, into a profitable trade for the actors involved in the process.

\subsection{Selling the Location in the City Centre}

The answers given by the land holders and users to the question "What does urban regeneration mean to you?" addressed to them within the scope of the field study show both their expectations from the urban regeneration project and how they perceive the gentrification process.

Within the scope of the questionnaires conducted with the Group 3 participants, the land holders and users were asked the question "What does urban regeneration mean to you?", and they were asked to rate the following options from 1 to 5: increase in the land value and financial gain, construction of earthquake-resistant buildings, increase in environmental quality, increase in socio-cultural facilities, moving/exile from Fikirtepe.

According to Chart 1, which was prepared based on the answers given by the land holders and participants, it is seen that the option of increase in the land value and financial gain got higher points than the other options which are solutions to problems which creates the need for urban regeneration such as increase in environmental quality, 
increase in socio-cultural facilities, construction of earthquake-resistant buildings.

Chart 2. Rating by land owners and users to express what urban regeneration mean to them

\begin{tabular}{|l|c|c|}
\hline What does urban regeneration mean to you? & Order & Rate \\
\hline Increase in land value and economic gain & 1 & 885 \\
Construction of earthquake-resistant buildings & 2 & 780 \\
Increase in environmental quality & 3 & 527 \\
Increase in socio-cultural facilities & 4 & 491 \\
Moving/exile from Fikirtepe & 5 & 336 \\
\hline Total & & 3019 \\
\hline
\end{tabular}

Despite the main reasons that make urban regeneration essential; illegal, dense and poor housing, buildings under disaster risk, poor physical conditions, limited access to social reinforcements, and lack of green areas; participants from Fikirtepe perceive the urban regeneration process as an increase in the land value and economic gain. In other words, the majority of land owners from Fikirtepe regard the gentrification process in the region as a means of economic gain.

Chart 3. The distribution of land owners' satisfaction with the increase in the land value by whether or not they will reside in Fikirtepe after the urban regeneration process

\begin{tabular}{|c|c|c|c|c|c|c|}
\hline \multirow{2}{*}{\multicolumn{2}{|c|}{$\begin{array}{l}\text { Are you going to continue to } \\
\text { reside in Fikirtepe after the urban } \\
\text { regeneration process? }\end{array}$}} & \multicolumn{4}{|c|}{$\begin{array}{l}\text { Are you happy with the increase in the land } \\
\text { value in Fikirtepe? }\end{array}$} & \multirow{2}{*}{ Total } \\
\hline & & $\begin{array}{c}\text { Very } \\
\text { dissatisfied }\end{array}$ & Dissatisfied & Satisfied & $\begin{array}{c}\text { Very } \\
\text { satisfied }\end{array}$ & \\
\hline \multirow{2}{*}{ Yes } & Number & 1 & 5 & 18 & 16 & 40 \\
\hline & Percentage & 0.70 & 3.60 & 12.90 & 11.50 & 28.80 \\
\hline \multirow{2}{*}{ No } & Number & 2 & 7 & 49 & 35 & 93 \\
\hline & Percentage & 1.40 & 5.00 & 35.30 & 25.20 & 66.90 \\
\hline \multirow{2}{*}{ No answer } & Number & 0 & 1 & 3 & 2 & 6 \\
\hline & Percentage & 0.00 & 0.70 & 2.20 & 1.40 & 4.30 \\
\hline \multirow{2}{*}{ Total } & Number & 3 & 13 & 70 & 53 & 139 \\
\hline & Percentage & 2.20 & 9.40 & 50.40 & 38.10 & 100.00 \\
\hline
\end{tabular}

The participants' responses to the questions show that they are happy with the increase in land value even though they will leave Fikirtepe after the urban regeneration process. Chart 3 makes a comparison between the satisfaction of the participants and whether or not they will continue to reside in Fikirtepe, and it is shown that the land owners do not complain about the gentrification process as long as they acquire economic gain at the end of the urban regeneration process. (Chart 3).

At the end of the urban regeneration process that the land owners regards as a means to obtain financial gain, they find it agreeable to leave the urban regeneration area and move to another part of the city, in return for economic gain. The only endeavour of the old settlers of Fikirtepe during the gentrification process was to increase their economic gain. Field study shows that the vast majority of the land owners are not concerned about staying in the city center, on the contrary, they expect to leave the city center in return for a satisfactory economic gain. This manner of land owners who want to sell their 
location in the city center in return for a satisfactory revenue shows that their location in the city center is now transformed into an exchange value and the use value of the city center is no longer important for them.

\subsection{Buying the Financial Gain of the City Centre}

The data obtained from the questionnaires conducted with the participants who prefer to make a real estate investment show that the primary expectation of the investors who prefer to buy real estate within the projects realised in Fikirtepe Urban Regeneration Area is to obtain financial gain.

Within the scope of the said questionnaire, the participants were asked why they preferred Fikirtepe for investment, and they were asked to give points to the following options in accordance with their importance: investment opportunities and the expected increase in the real estate value, central location, transportation facilities, building quality, accessibility to the socio-cultural facilities, living standards, social reinforcement and abundance of green areas, because you love Fikirtepe.

In Chart 4, which was prepared according to the points given by the investors, it is seen that the highest point was given to the option of investment opportunities/expected increase in the real estate value. This option is followed by central location and transportation facilities. And, even tough they are the main components of the need for urban regeneration, it is seen that options such as building quality, accessibility to the socio-cultural facilities, living standards, social reinforcement and abundance of green areas ranked lower in the chart.

Chart 4. The Reasons Why Investors Prefer Fikirtepe

\begin{tabular}{|l|c|c|}
\hline Why did you prefer Fikirtepe for investment? & Order & Points \\
\hline Investment opportunities/expected increase in the real estate value. & 1 & 450 \\
Central Location & 2 & 446 \\
Transportation facilities & 4 & 407 \\
Building quality & 5 & 385 \\
Accessibility to the socio-cultural facilities & 6 & 379 \\
Living standards & 7 & 377 \\
Social reinforcement and abundance of green areas & 8 & 370 \\
Because you love Fikirtepe & 9 & 250 \\
\hline Total & & 3508 \\
\hline
\end{tabular}

40 of out 97 participants said they will live in the real estate themselves, 36 said they will rent the real estate, and 20 said they will sell the real estate. (Chart 5).

Chart 5. The ways the investors utilise the real estate that they bought

\begin{tabular}{|l|c|c|}
\hline How are you going to utilise the real estate you bought in Fikirtepe? & Number & Percentage \\
\hline Residence & 40 & 41.20 \\
Renting & 36 & 37.10 \\
Selling & 20 & 20.60 \\
No answer & 1 & 1.00 \\
\hline Total & 97 & 100.0 \\
\hline
\end{tabular}


The majority of the investors who bought real estate in Fikirtepe preferred to by $1+1$ apartments. It is seen that the number of investors who preferred to buy $3+1$ and $4+1$ apartments is much lower. Out of 97 participants, it is seen that the number of those who preferred to buy $1+0$ apartments is 5 , the number of those who preferred $1+1$ is 42 , while the number of those who preferred $3+1$ is 2 , and the number of those who preferred $4+1$ is 1 . (Chart 6$)$.

Chart 6. The type of real estate that the investors bought in Fikirtepe

\begin{tabular}{|c|c|c|}
\hline Which apartment type did you buy in Fikirtepe Urban Regeneration Area? & Number & Points \\
\hline $1+0$ & 5 & 5.20 \\
$1+1$ & 42 & 43.30 \\
$2+1$ & 31 & 32.00 \\
$3+1$ & 16 & 16.50 \\
$4+1$ & 2 & 2.10 \\
No answer & 1 & 1.00 \\
\hline Total & 97 & 100.00 \\
\hline
\end{tabular}

The results of the field study show that the investors buy the real estate as an investment, and the majority of them will either sell or rent their real estates.

The data obtained in the field study indicates that those who buy real estate from the urban regeneration projects expect a financial gain that will stem from the increase in the land value.

In other words, the participants buy real estate from the regeneration area in the city center as a means to provide them with financial gain. For the investors in question, the city center represents an exchange value that will provide them with financial gain, and it has nothing to do with the use value.

\section{Evaluation; The Relationship Between the Disappearing Use Value of Urban Space and Gentrification}

The study sheds light both on the gentrification process that took place in Fikirtepe urban Regeneration Area, and on the direction of movement of the population that left the gentrified area. $72.5 \%$ of the population that left the Urban Regeneration Area settled outside the line which is assumed to determine the borders of the city center, that is, they moved away from the city center. The vast majority of the land holders moved away from the center and left the city center.

The results of the study show that gentrification is a process of obtaining financial gain not only for the land holders but also for the investors who bought real estate within the urban regeneration area. The vast majority of the land holders are not concerned about remaining in the city center, on the contrary, they want to sell their locations in the city center in return for financial gain. In other words, land holders yield returns by selling the advantageous location of the city center during the gentrification process.

On the other hand, those who buy real estate from the projects realised in the urban regeneration area, that is, the new owners of the gentrified area also expect financial gain. The new owners of the gentrified urban regeneration area are in fact buying the 
economic rent of the city center. Gentrification process is a trade-off not only for the new owners of the urban regeneration area, but also for the old settlers.

The most important output of the study is the relationship between the gentrification process and the lost use value of the city center. Both old and new owners have an expectation of obtaining financial gain throughout the urban regeneration process, which results in the exchange value of the city center.The size of the rent-gap emerging during the urban regeneration process turns gentrification into a process of obtaining financial gain both for the old and the new owners of the city center. Thus, city center completely loses its use value for the actors of the gentrification process.

\section{References}

E. Soytemel, B. Şen: Kentsel Mekanda Üçlü İttifak, İstanbul Üniversitesi İktisat Fakültesi Dergisi, 44, March 2011, 1-21.

N. Sam: Soylulaştırma Süreçlerine Ekonomik Bir Yaklaşım: Rant Farkı, Marmara Üniversitesi I.I..B.F Dergisi, 29 (2), 133-151, 2010.

N. Smith: Gentrification, The Frontier and The Restructuring of Urban Space, (Eds N. Smith and P. Williams), Gentrification of the City, 15-34, Routledge, 2013.

B. Şen: Kentsel Mekanda Üçlü İttifak, İstanbul Üniversitesi İktisat Fakültesi Dergisi, 44, March 2011, 1-21.

D. Harvey: Sosyal Adalet ve Şehir, İstanbul:Metis Yayınları, 2003.

N. Smith: Toward a Theory Of Gentrification: A Back to the City Movement by Capital, Not People, Journal of American Planners Association, 45 (4), 538-548, 1979. 